\title{
Historical biogeography and interspecific mtDNA introgression in Euhadra peliomphala (the Japanese land snail)
}

\author{
YUICHIRO SHIMIZU † \& REI UESHIMA †ः* \\ $\dagger$ Department of Biological Sciences, University of Tokyo, 7-3-1 Hongo, Bunkyo-ku, Tokyo 113-0033, Japan, \\ $\ddagger$ PRESTO, Japan Science and Technology Corporation
}

\begin{abstract}
We assess variation in mitochondrial DNA (mtDNA) using partial sequences (560 bp) of the COI gene among populations of Japanese land snails, Euhadra peliomphala. Phylogeographical analysis reveals five primary clades that correspond basically to five discrete areas: the Boso Peninsula (B), the Kanto area (K), around Lake Ashinoko (A), the Northern Izu Peninsula (N), and the Southern Izu Peninsula (S). Although there are no current geographical barriers separating these five subpopulations, the borders between each area correspond to palaeogeographical events during the Pleistocene, such as volcanic activities and the disappearance of the landbridge between the Southern Boso area and the mainland of Japan. In addition, our analysis of isolation-by-distance and the distribution of pairwise sequence differences indicate that haplotypes of the $\mathrm{B}$ and $\mathrm{K}$ lineages have recently increased their population size exponentially. We have also discovered interspecific mtDNA introgression between E. peliomphala and the parapatric species E. brandtii at the contact zone in the Northern Kanto area. Unexpectedly, the E. brandtii-type mtDNA was also found in the populations of $E$. peliomphala in the Southern Boso area. Because recent contact between both species is unlikely, the introgressed mtDNA of E. brandtii could be a remnant of past hybridization, when E. peliomphala colonized this area via the landbridge that existed in the early Pleistocene.
\end{abstract}

Keywords: biogeography, Euhadra peliomphala, land snail, mtDNA introgression, Pleistocene, population genetic structure.

\section{Introduction}

Species with low dispersal ability and/or a narrow ecological niche have a tendency towards small-scale geographical isolation. The fragmentation of their habitat may reduce the amount of gene flow between populations, and the lack of genetic exchange allows different evolutionary histories to take place in each of the separated populations. As a result, local genetic differentiation may arise. Thus, the population genetic structure usually reflects the long-term structure and the demographic history of populations. These traits have been considered suitable for understanding the evolutionary forces that influence the origin and maintenance of population genetic structure.

The limited mobility and requirement of humidity make land snails an excellent model for studying intraspecific population genetic structure, because the

*Correspondence: E-mail: rueshima@biol.s.u-tokyo.ac.jp population is prone to fragmentation by habitat disturbance. In fact, a considerable number of such studies using land snails have been reported (e.g. Jones et al., 1980; Arter, 1990; Schilthuizen \& Lombaerts, 1994; Pfenninger et al., 1996; Thomaz et al., 1996; Chiba, 1998; Douris et al., 1998).

Recently, mitochondrial DNA (mtDNA) analysis has been demonstrated to be a powerful tool for tracing recent evolutionary history, such as founder events, population bottlenecks, and population range fluctuation (Bermingham \& Avise, 1986; Ellsworth et al., 1994; Zink, 1994; Wooding \& Ward, 1997; for review, see Avise et al., 1987), mainly because of its maternal inheritance without recombination and high mutation rate. Also, since the effective population size for mtDNA is smaller than that for the nuclear genes, populations are susceptible to the process of mitochondrial lineage extinction (Hutchinson et al., 1974; Brown et al., 1979; DeSalle et al., 1987; Harrison, 1989). A strict geographical partitioning of mtDNA lineages is often found in animal species with low or moderate 
dispersal abilities (Lunt et al., 1998; Hanfling \& Brandl, 1998; Knoll \& Rowell-Rahier, 1998).

In this study, the genetic variation of the land snail Euhadra peliomphala was analysed using the nucleotide sequences of mtDNA cytochrome oxidase subunit I (COI) gene. E. peliomphala is a hermaphrodite land snail which is widely distributed around the Izu Peninsula and the Kanto area, Japan. As this species is arboreal, populations are likely to be easily isolated from each other if the habitat is distributed patchily. Based on the shell morphology, E. peliomphala is divided into several subspecies. This reflects the existence of intraspecific geographical variation. However, because few genetic studies on this particular species have been reported, and because the regional differences in morphological characters may not be based on genetic components (e.g. James, 1983), investigating the population genetic structure of E. peliomphala using molecular markers is necessary to resolve the evolutionary history of this land snail. In addition, the area inhabited by E. peliomphala, which lies around the Izu Peninsula and the Kanto area, has experienced various tectonic movements and fluctuations of the coastline since the early Pleistocene. Therefore, it is possible that the effects of relatively recent palaeogeographical events might be reflected in mtDNA variation.

We had two general objectives in this study. First, we examined the spatial distribution of evolutionary lineages of E. peliomphala at the scale of the entire species range by analysing the mtDNA nucleotide sequence polymorphism, to determine whether distinct patterns of distribution are present. Secondly, in conjunction with palaeogeographical data, the dynamics of population genetic structure were analysed in order to reconstruct the evolutionary history of this land snail.

\section{Materials and methods}

\section{Samples}

A total of 165 snails of Euhadra peliomphala were collected from 82 locations. Sampling of the populations was designed to cover the entire distribution range of the species (Fig. 1, Table 1). Forty-three individuals of $E$. brandtii from 15 localities were also examined for the analysis, because this closely related species has contact with E. peliomphala in its natural habitat (see below). Other congeneric species and outgroup taxa examined (a)

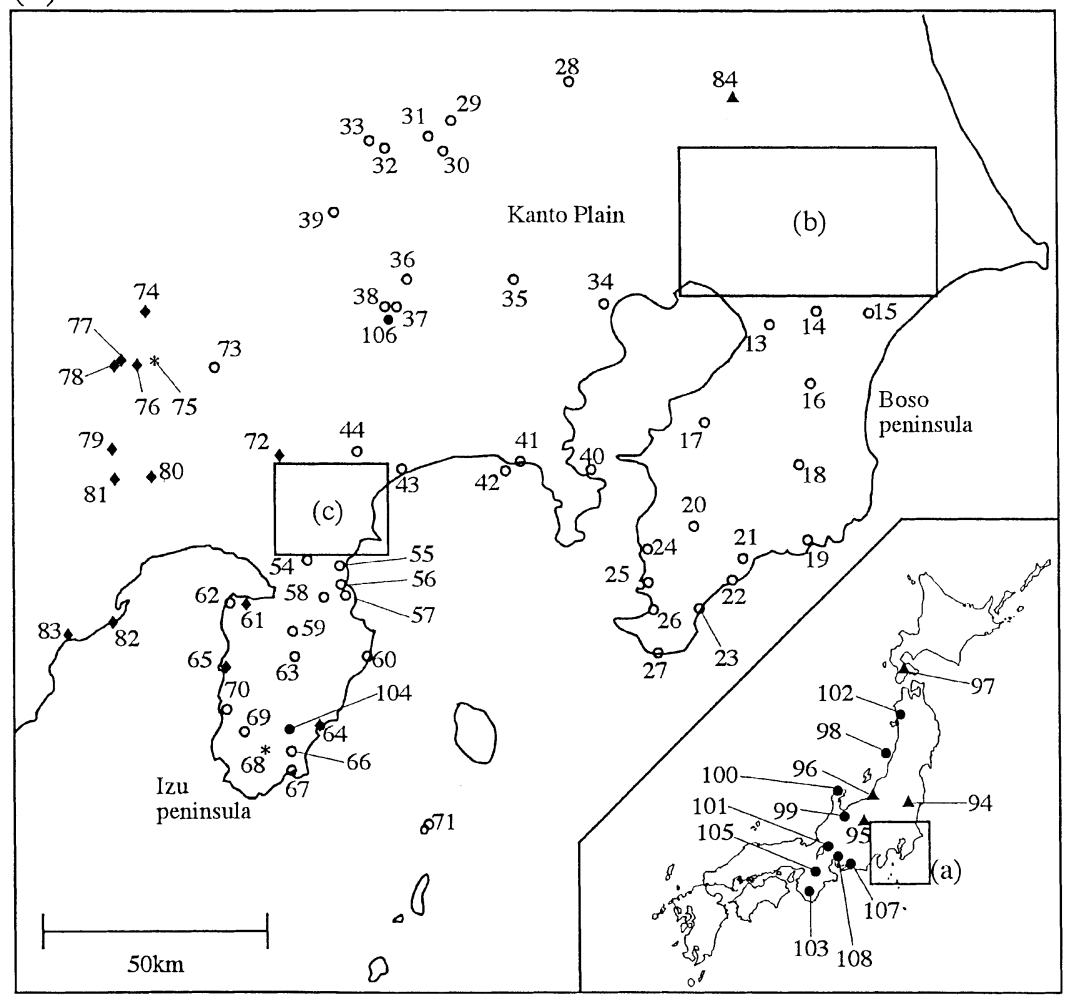

(b)

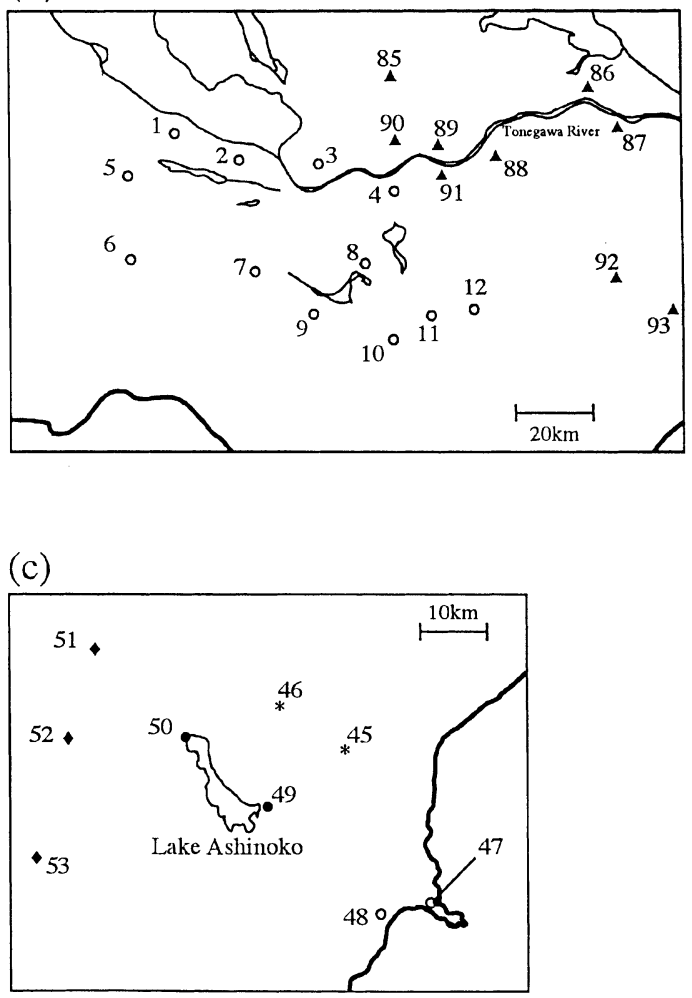

Fig. 1 Map showing the sampling localities of the land snails used in this study. The localities inhabited by E. peliomphala, E. 'p.' kunoensis and E. brandtii are shown in open circles, filled diamonds, and filled triangles, respectively. Mixed populations of E. peliomphala and E. 'p.' kunoensis are shown in asterisks. Locality numbers correspond to Table 1.

(C) The Genetical Society of Great Britain, Heredity, 85, 84-96. 
Table 1 Samples used in this study

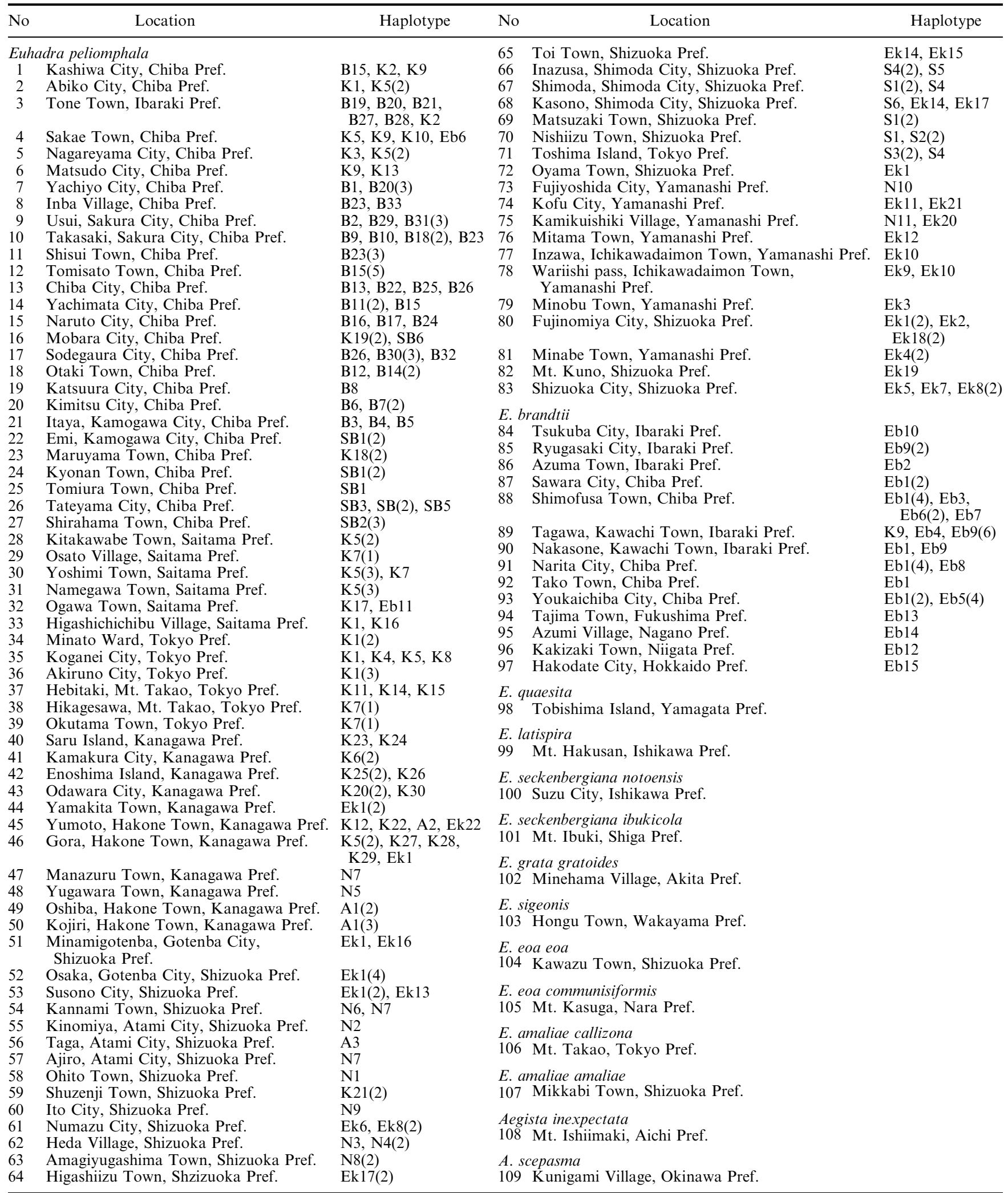

B, K, A, N, and S correspond to the clades within E. peliomphala and Eb corresponds to E. brandtii clade in Fig. 3. Numbers within parentheses next to the haplotypes represent the numbers of the haplotypes observed. Haplotypes with no parentheses represent that only one haplotype was found in the collection site. 
are shown in Table 1. The identification of E. peliomphala, E. 'p.' kunoensis, and E. brandtii was based on their characteristic shell morphology. All the other species or subspecies used in this study were identified by their conchological and anatomical features. The gonads or hepatopancreas were dissected from each snail and kept frozen at $-80^{\circ} \mathrm{C}$ before use in the experiments.

\section{DNA extraction, amplification and sequencing}

The standard protocols for the DNA experiments were carried out as described in Sambrook et al. (1989) with some modifications. For extraction of total genomic DNA, the frozen tissue was homogenized in the homogenization buffer (10 mm Tris-Cl, pH 7.5; 100 mm EDTA, $\mathrm{pH} 7.5$ ) and $1 / 25$ volume of $20 \%$ SDS was added to the homogenate to lyse the cells, followed by the phenol/ chloroform extraction. Then, the DNA was ethanol precipitated and was rinsed with $70 \%$ ethanol. After drying the DNA pellet, it was resuspended in $350 \mu \mathrm{L} \mathrm{TE}$ buffer [10 mм Tris-Cl (pH 7.5); 1 mм EDTA (pH 7.5)]. The solution of extracted DNA was further purified by incubation at $65^{\circ} \mathrm{C}$ for $30 \mathrm{~min}$ with $1 / 2$ volume of CTAB/RNase buffer [2 $\mathrm{m} \mathrm{NaCl} ; 3 \%$ CTAB (Hexadecyl trimethyl ammonium bromide); $10 \mu \mathrm{g} \mathrm{mL}^{-1}$ RnaseA]. Further cycles of the phenol/chloroform extraction and ethanol precipitation were carried out in succession. The total genomic DNA was resuspended in $200-350 \mu \mathrm{L}$ TE buffer, and the final concentrations of the DNA solutions were approximately $0.1 \mu \mathrm{g} \mu \mathrm{L}^{-1}$. The mtCOI fragment was amplified with the polymerase chain reaction (PCR) method using degenerate primers, which were constructed based on the published amino acid sequences of other metazoans. The primers were: COI-7 (5'-ACN AAY CAY AAR GAY ATY GGN AC-3'), and COI-6R (5'-TCN GGR TAR TCN SWR TAN CGN CG-3'). The PCR was conducted using the following protocol: $1 \mathrm{~min}$ at $94^{\circ} \mathrm{C}$ (initial denaturation) and 30 cycles of $30 \mathrm{~s}$ at $94^{\circ} \mathrm{C}$ (denaturation), $1 \mathrm{~min}$ at $45^{\circ} \mathrm{C}$ (annealing), and $2 \mathrm{~min}$ at $72^{\circ} \mathrm{C}$ (extension). An additional extension of $2 \mathrm{~min}$ followed after the 30 cycles. The $20 \mu \mathrm{L}$ of reaction solution contained $0.5 \mu \mathrm{L}$ template DNA, 16 pmol primers, $1.6 \mu \mathrm{L}$ dNTP mixture, $5 \mu \mathrm{L} \mathrm{10 \times} \mathrm{ExTaq} \mathrm{buffer} \mathrm{and} 2.5$ units ExTaq polymerase (Takara). The amplified $1.3 \mathrm{kbp}$ fragment was gelpurified with Prep-A-Gene DNA purification systems (Bio-Rad), according to the supplier's recommendation, and was used as template DNA for the sequencing reaction. Sequences were determined by the dideoxy chain-termination method (Sanger et al., 1977) using ABI Prism BigDye Terminator Cycle Sequencing Ready Reaction Kit (Applied Biosystems) or Thermo sequenase dye terminator cycle sequencing premix kit v2.0 (Amersham) following the manufacturer's recommen- dations. The primers used for the sequencing reactions were: COI-20 (5'-YTN TTY GGN GTN TGR TGY GG-3'), and COI-DR (5'-TCN GGR TGN CCR AAR AAY CAR AA-3'). Nucleotide sequences of $560 \mathrm{bp}$ were determined directly in both strands by an ABI 377 automated sequencer (Perkin-Elmer).

The nucleotide sequence data reported in this paper will appear in the DDBJ/EMBL/GenBank nucleotide sequence databases with the accession numbers from AB024764 to AB024900.

\section{Data analysis}

The sequences obtained were aligned by using the computer software CLUSTAL w (Thompson et al., 1994), and the alignment data were transported into the PHYLIP v3.572c package (Felsenstein, 1989). Nucleotide distances (substitutions per site) were calculated using the DNADIST program of PHYLIP, under the assumptions of the Kimura two-parameter model (Kimura, 1980). Neighbor-Joining (Saitou \& Nei, 1987) trees were constructed and visualized using the NEIGHBOUR program of PHYLIP, and DENDROMAKER v4.1 for Macintosh (Imanishi, 1998), respectively. In order to test the reliability of the trees thus obtained, 1000 bootstrap resamplings were performed with the SEQBOOT program of PHYLIP.

The expected values of the nucleotide pairwise difference distributions were calculated using equation (4) of Rogers \& Harpending (1992) using the DNASP v3.0 program (Rozas \& Rozas, 1999). By setting $\theta_{1}(\theta$ after the population growth) as infinite, $\theta_{0}(\theta$ before the population growth) and $\tau$ were estimated using the method of Rogers (1995), where $\theta$ is the expected pairwise difference, and $\tau$ is the mutational timescale (see Rogers \& Harpending, 1992).

To detect isolation-by-distance, the associations between geographical distances and genetic distances were tested using regression analysis. The data for genetic distances calculated in the phylogenetical analysis were also applied in this test. Geographical distances were measured from a 1:250 000-scale map.

\section{Results}

\section{Phylogenetic relationships within the genus Euhadra}

Before investigating the population genetic structure of E. peliomphala, we first examined the phylogenetic position of E. peliomphala within the genus Euhadra. The phylogeny of the Euhadra species has been constructed previously based only on shell morphology (Kuroda \& Teramachi, 1937), and thus molecular 


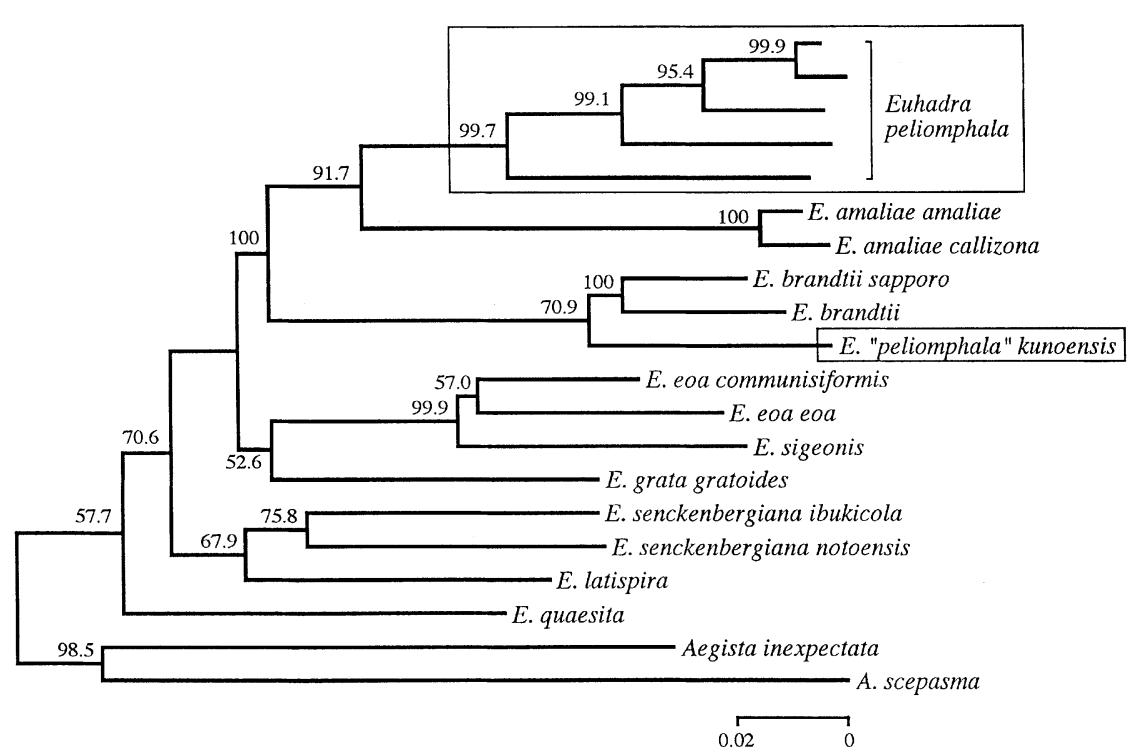

Fig. 2 Neighbor-joining tree summarizing the genetic relationships among species of genus Euhadra based on mtCOI sequences. Numbers on branches represent the percentage of the bootstrap values above $50 \%$. Six samples of E. peliomphala are boxed. A. inexpectata and $A$. scepasma are used as outgroups. confirmation was needed. To reconstruct the specieslevel relationships of the genus Euhadra, a phylogenetic analysis of the mtCOI gene sequence for several species of Euhadra (including six samples of E. peliomphala from throughout species' range) was performed using two species of the genus Aegista as an outgroup (Fig. 2). In the current taxonomy of the family Bradybaenidae, Euhadra and Aegista are classified as being in the same subfamily, Aegistinae, based on their genital features. Thus, Aegista is an appropriate outgroup for Euhadra. The topology of the tree constructed using the Neighbor-Joining (NJ) method was identical to the Maximum-Parsimony (MP) tree (data not shown). The dendrogram showed that E. peliomphala was divided into two distinct clades. Five out of six samples formed a monophyletic cluster. The monophyly of these clades were supported by high bootstrap values $(99.8 \%)$ ). Surprisingly, E. 'peliomphala' kunoensis clustered with the distinct species E. brandtii, although E. ' $p$.' kunoensis has been regarded as a subspecies of E. peliomphala. Also, E. amaliae amaliae and E. amaliae callizona were placed between E. peliomphala and E. 'p.' kunoensis. Therefore, in this study, we decided to treat E. 'peliomphala' kunoensis as a distinct species.

\section{Phylogeographic analysis of E. peliomphala}

The NJ tree based on populations of E. peliomphala from throughout its range is shown in Fig. 3. Some populations of E. 'p.' kunoensis and E. brandtii were also analysed in the same tree. The tree was separated into two lineages, one representing E. peliomphala and the other E. 'p.' kunoensis and E. brandtii.
Within the mtDNA lineages of E. peliomphala, there were five distinct monophyletic subclades, which had high levels of intraspecific nucleotide differences (up to $13.1 \%$ in Kimura's distance). The monophyly of these clades were strongly supported by the high bootstrap values $(100,97.2,96.1,100$, and $100 \%$, Fig. 3), and the general topology was identical to that of the MP tree (data not shown).

These five genetic groups in E. peliomphala are strongly patterned geographically in five separate areas: the Boso Peninsula, the Kanto Plain, around Lake Ashinoko, the Northern Izu Peninsula, and the Southern Izu Peninsula. According to the name of the five areas, we designated the five mt-lineages (haplotype groups) as $\mathrm{B}, \mathrm{K}, \mathrm{A}, \mathrm{N}$, and $\mathrm{S}$, respectively, with some exceptional localities, 16, 23, 56, 59, 73, and 75 (Figs 1, 3, 4, Table 1).

Interestingly, populations of E. peliomphala in the Southern Boso Peninsula were clustered within a monophyletic clade of a distinct species, E. brandtii. They are designated as SB in Figs 3 and 4. The existence of such unusual haplotypes may reflect evolutionary interactions between E. peliomphala and E. brandtii in the past (see Discussion).

\section{Regression analysis between geographical and genetic distance}

In order to understand the recent history of each haplotype, isolation-by-distance was tested in each group of haplotypes by regression analysis between geographical and genetic distances (Table 2). A significant positive slope of genetic distance against geographical distance indicates the dominance of isolation-by-distance. As 


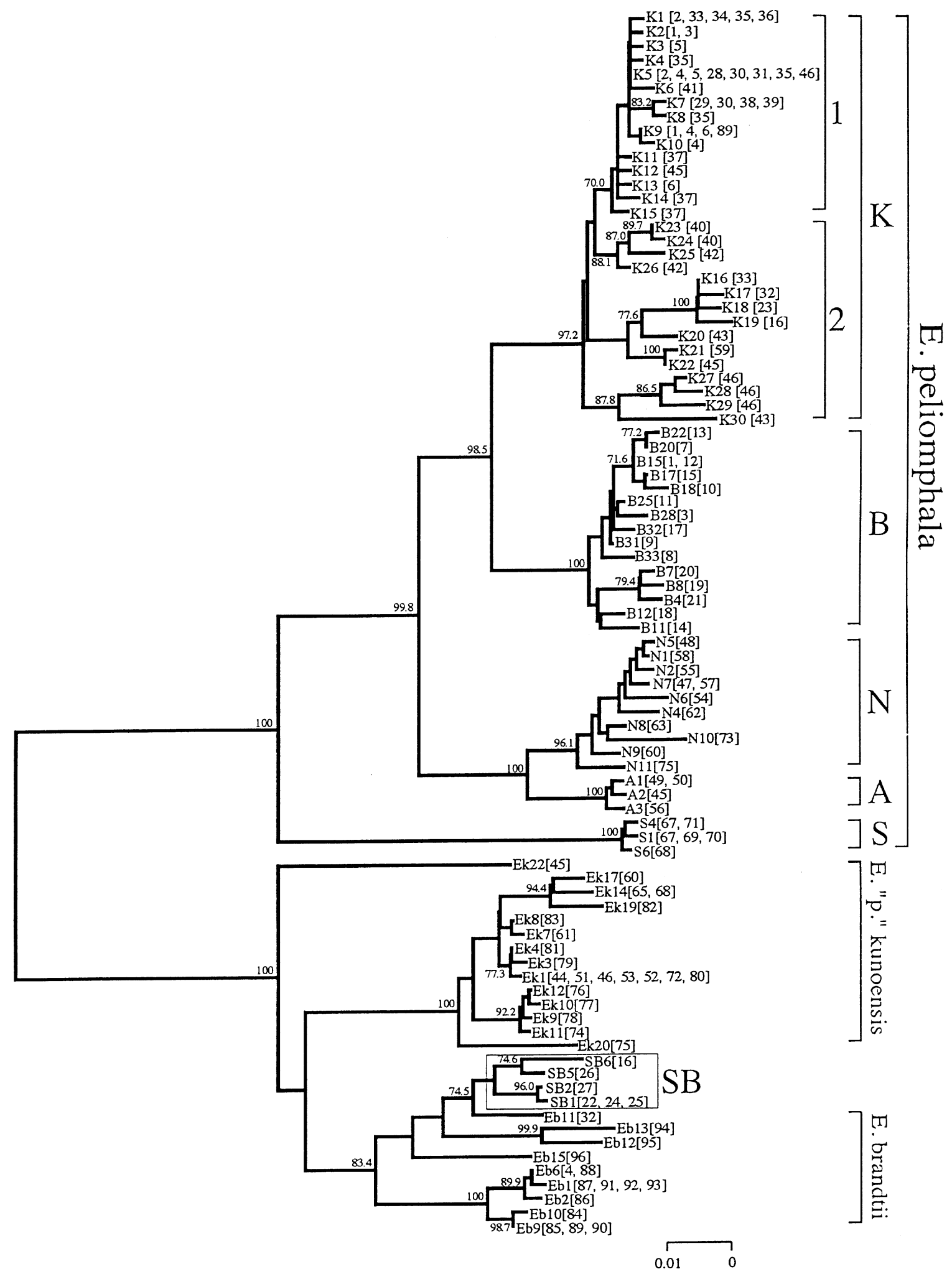

Fig. 3 Neighbor-joining tree showing the genetic relationships among haplotypes of E. peliomphala and E. brandtii obtained from analysis of mtCOI sequences. Numbers on branches represent the percentage of the bootstrap values above $70 \%$. Numbers in parentheses represent localities at which haplotypes were detected. Haplotypes and numbers of localities correspond to Table 1. For clarity of the tree, basically one individual per one locality except all of the haplotypes $\mathrm{K}$ are used.

(C) The Genetical Society of Great Britain, Heredity, 85, 84-96. 


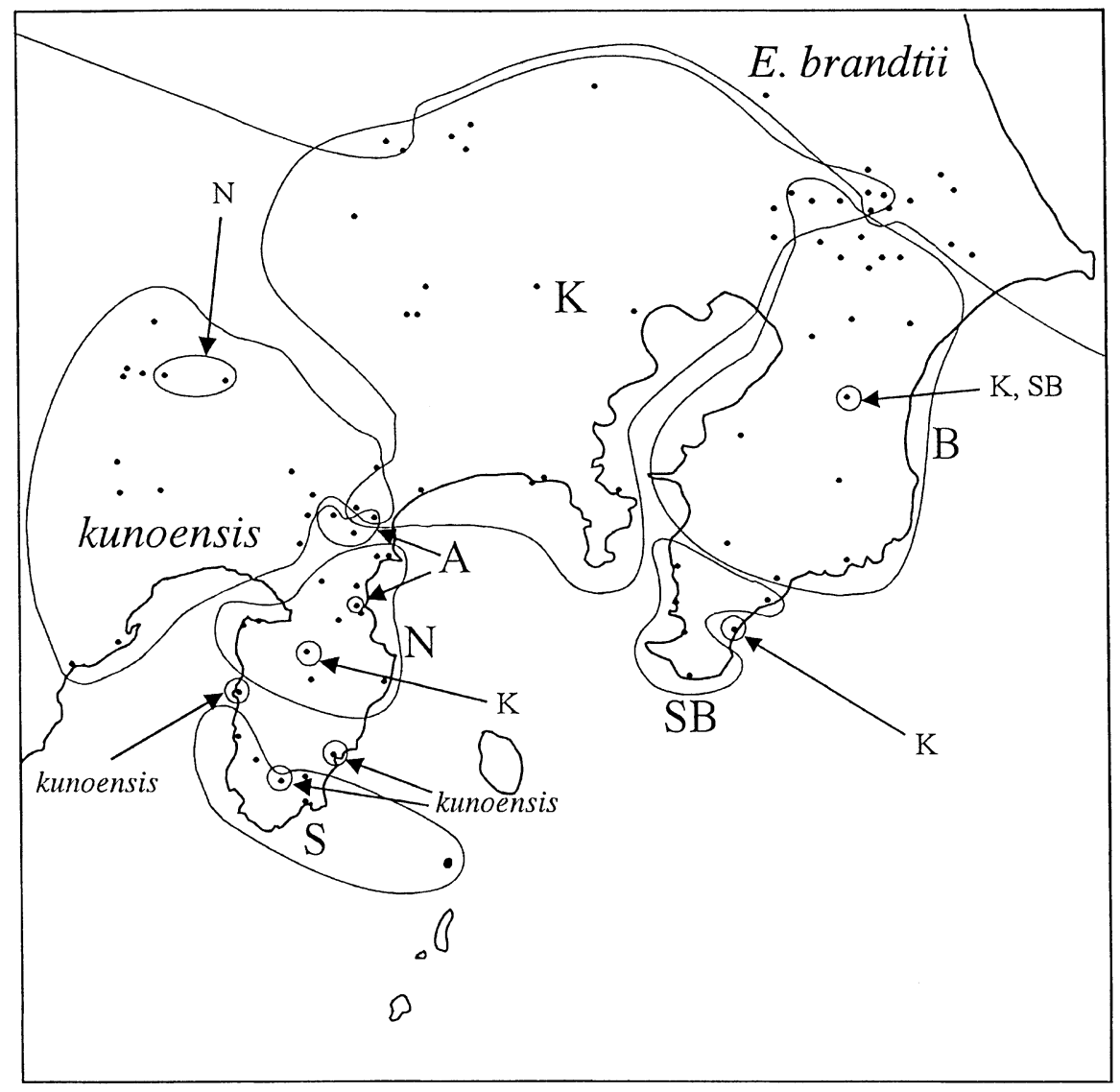

Fig. 4 Distributions of the haplotypes which correspond to Fig. 3.
Table 2 Regressions between genetic and geographical distances

\begin{tabular}{lcc}
\hline Haplotype & $n$ & $R^{2}$ \\
\hline $\mathrm{B}$ & 55 & 0.054 \\
$\mathrm{~K}$ & 55 & 0.057 \\
$\mathrm{~K}+$ isolated area* & 66 & 0.097 \\
$\mathrm{~N}$ & 13 & 0.219 \\
$\mathrm{~N}+$ isolated area** & 15 & 0.553 \\
$\mathrm{~S}$ & 12 & 0.014 \\
\hline
\end{tabular}

$R^{2}$ represents the correlation coefficients of the regressions.

* populations $16,23,59$; ** populations 73 and 75 .

isolation-by-distance assumes the genetic properties of a continuous population (Wright, 1946), populations located outside the main distributions of each haplotype (i.e. populations $16,23,59,73$, and 75 ) or populations collected from islands (i.e. populations 40,42 , and 71) were disregarded. Haplotypes of the $\mathrm{B}(n=55), \mathrm{K}$ $(n=55)$, and $\mathrm{S}(n=12)$ lineages revealed, in each case, that there was weak correlation between the two distances $\left(R^{2}=0.054,0.057\right.$, and 0.014 , respectively; Table 2). Two explanations are possible for this pattern. Either the range expansion of these haplotypes has occurred so recently that mutations have not yet accumulated, or the correlations between the two distances might have been disrupted because mutation has become saturated. However, haplotypes of the $\mathrm{N}$ lineage appeared to show a positive relationship $\left(R^{2}=0.219\right.$, Table 2).

We also tested isolation-by-distance of haplotypes $\mathrm{K}$ and $\mathrm{N}$, but now including the isolated areas previously excluded because exclusion of these areas may have hidden the evidence of geographical patterns (Table 2). $\mathrm{R}^{2}$ increased from 0.057 to 0.097 for haplotypes $\mathrm{K}$ and from 0.219 to 0.533 for the Northern Izu haplotype.

[Another haplotype, A, was not dealt with in this and in the next analysis, because the number of samples collected in this study was too small $(n=5)$.]

\section{Pairwise difference distributions}

We investigated the population genetic dynamics further by examining the distribution of sequence differences between all possible pairs of the four major mt-lineages (i.e. B, K, N, and S) (Fig. 5). If an observed distribution of pairwise differences is close to a Poisson curve, this may indicate a population that has been growing 
Fig. 5 Distributions of sequence differences for all possible pairs of individuals in each populations. d-2 and d-3 represents the histogram of pairwise differences within group 1 of the Kanto hapkotype, and the remaining pairs in the Kanto haplotype, respectively. Pairwise differences within group 2 of the Kanto haplotype are shown in d-3 with shaded bars. Group 1 and 2 corresponds to Fig. 3. Solid lines show the expected distribution estimated with the equation 4 of Rogers \& Harpending (1992). $\theta_{0}$ and $\tau$ were estimated by estimating $\theta_{1}$ as infinite (Rogers, 1995). (a) Boso

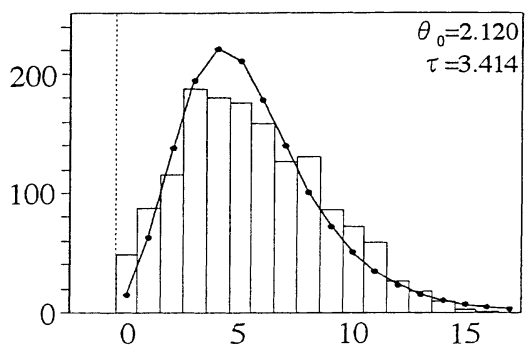

(b) Northern Izu
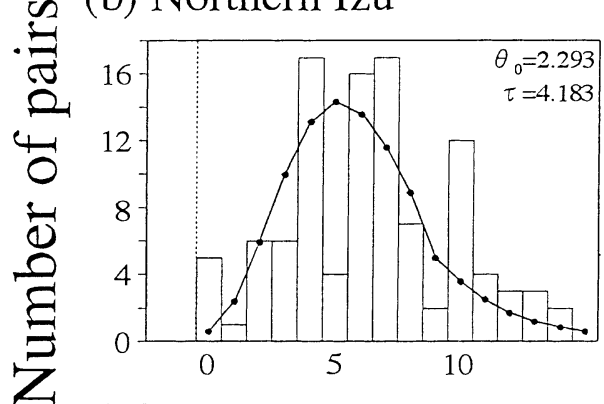

(c) Southern Izu

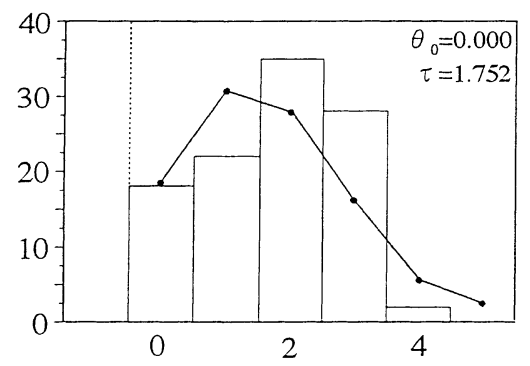

(d-1) Kanto

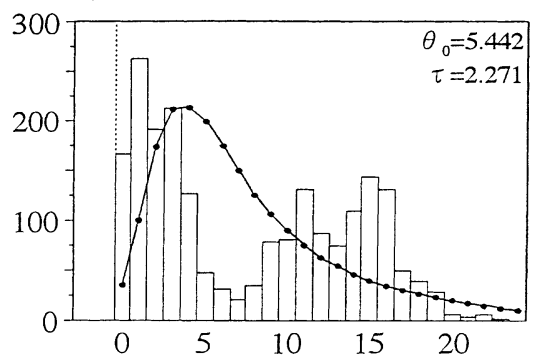

$(\mathrm{d}-2)$

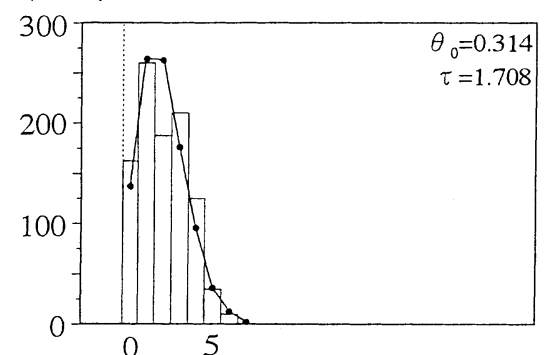

(d-3)

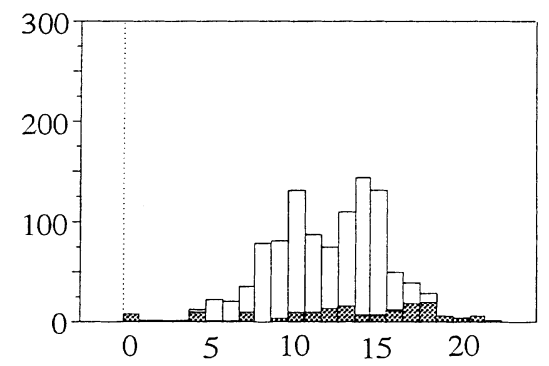

\section{Nucleotide differences}

exponentially in size (Slatkin \& Hudson, 1991). However, a unimodal distribution of pairwise differences may also be the consequence of selection (Di Rienzo \& Wilson, 1991).

The haplotypes of the $\mathrm{B}$ lineage reveal a clear unimodal distribution, which has high similarity with the expected pattern (Fig. 5a). The haplotypes of the $\mathrm{K}$ lineage show a bimodal distribution of sequence differences (Fig. 5d). A bimodal distribution usually implies that each peak reflects the pairwise nucleotide difference, respectively, within and between the different lineages. Based on the phylogenetic relationships among haplotypes, the $\mathrm{K}$ lineage can be divided into two groups in the phylogenetic tree (Fig. 3). One consists of a single monophyletic clade with small differentiation (group 1), and the other is the remainder with rather high differentiation (group 2). The left mode in the histogram shown in Fig. 5(d) represents mainly the distribution of pairwise differences within group 1 (Fig. 5e), and the right mode is derived from the differences between the rest of the pairs in the $\mathrm{K}$ lineage (Fig. 5f). The left mode also seems to fit to the expected pattern.

On the other hand, the haplotypes of the $\mathrm{N}$ lineage showed a different pattern, with many modes (Fig. 5b), which appears not to fit to the estimated curve. The haplotypes of S lineage showed a unimodal pattern, but also seems to disagree with the expected values.

\section{Interspecific mtDNA introgressions} between $\mathrm{E}$. peliomphala and $\mathrm{E}$. brandtii

In the contact zone of E. peliomphala and E. brandtii, we detected interspecific mtDNA introgression in two individuals (Table 1). One individual in population 4 $(n=4)$ had mtDNA which belonging to E. brandtii lineages, although the morphology of the shell showed 
the prominent $E$. peliomphala type. On the other hand, in population $89(n=8)$ there was one snail which possessed the mtDNA of the E. peliomphala haplotype in spite of having the morphological phenotype of E. brandtii.

\section{Discussion}

\section{The geography of the mtDNA variation}

A strongly structured phylogenetic topology is demonstrated by our survey of mtDNA diversity of the land snail E. peliomphala (Fig. 3). One of the most striking features is the presence of five distinct clades. In addition, each clade shows spatial clustering, being distributed into the five primary geographical regions (Fig. 4). This pattern of population genetic structure indicates the existence of long-term extrinsic (e.g. zoogeographical) barriers to gene flow. While no such barriers at the border of each lineage are likely to exist now, they might have prevented the movement of land snails in the past.

Two million years ago (Ma), the Kanto Plain and the northern part of the Boso Peninsula, where lineages B and $\mathrm{K}$ are in contact, were under the sea. Around the same time, however, there was a landbridge between the southern part of the Boso area and mainland of Japan (Fig. 6a, Fujita et al., 1986). This landbridge disappeared following rising sea level in the early to middle Pleistocene (2.0-0.14 Ma) (Fig. 6b, Fujita et al., 1986) and the Southern Boso area became an island. The land snails that migrated into the Southern Boso area were highly likely to be isolated in the island after this landbridge disappeared, making gene flow between the Boso and the Kanto regions impossible. This barrier seems to correspond to the border between the major distribution ranges of the haplotypes $\mathrm{B}$ and $\mathrm{K}$.
During the same epoch, in middle Pleistocene times (0.7-0.14 Ma), volcanoes became highly active in the northern part of the Izu Peninsula (Fig. 6b, Kurasawa, 1972). As a result, the land snails that inhabited these regions might have died out and their distribution range would have retreated into volcanic refugia surrounded by uninhabitable areas. Moreover, the volcanoes had a ring-like distribution at that time. If the volcanoes worked as effective barriers to gene flow, the distribution of E. peliomphala would have been divided into three geographical areas, namely the Northern Izu Peninsula, the Southern Izu Peninsula, and the area east to the Izu Peninsula. These three areas are consistent with the distributions of the haplotypes of $\mathrm{A}+\mathrm{N}, \mathrm{S}$, and the $\mathrm{K}$ lineage, respectively (Fig. 4).

A population genetic structure influenced by volcanic activities was also reported in Drosophila silvestris, which is endemic to Hawaii (Carson et al., 1990). Carson et al. (1990) argued that volcanic activity in Hawaii not only formed the islands upon which life could diversify, but may also have played a direct role in the acceleration of evolutionary processes as they operate in local populations. This parallels our case of land snails, because volcanic activities appear to have affected the lineage extinction and movements of E. peliomphala.

Thus, the disappearance of the land bridge which connected the Southern Boso area to the mainland of Japan, and volcanic activity in the Izu Peninsula during the middle Pleistocene $(0.7-0.14 \mathrm{Ma})$ were likely responsible for dividing the habitat into four regions, now reflected in the distributions of the haplotypes $\mathrm{B}, \mathrm{K}$, $\mathrm{A}+\mathrm{N}$, and $\mathrm{S}$.

However, there are several populations that are located outside the main distribution of each haplotype (populations 16, 23, 56, 59, 73, and 75). This unusual distribution of haplotypes suggests (i) vestiges of the (a) $2 \mathrm{Ma}$

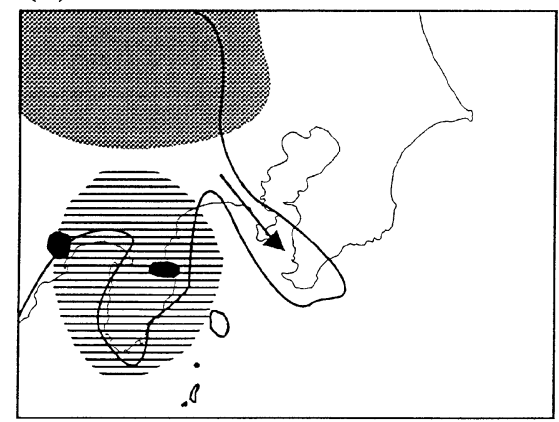

(b) $0.5 \mathrm{Ma}$

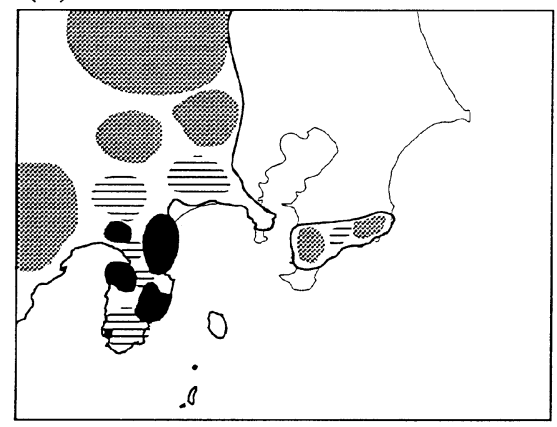

(c) 20,000 BP

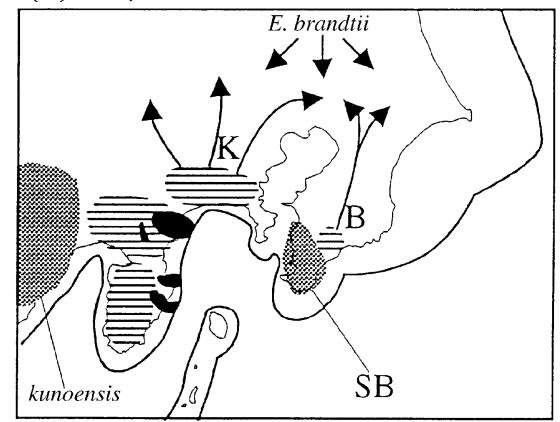

Fig. 6 Palaeogeographic maps around Izu and Kanto area, Japan, and the hypothesis for the ancient movement of E. peliomphala and E. brandtii. Coastlines are shown in bold lines. The present coastline is shown in a narrow line. The black area represents the distributions of the volcanic activities. The range of E. peliomphala is shown in striped zone, and that of $E$. brandtii is shown in shaded zone. Arrows in (c) show the postglacial movement of the land snails. 
past distribution of the haplotypes and/or (ii) the result of human dispersal. As this species usually inhabits urban areas, passive human transport is possible.

Because the period of isolation was too short to generate the distinct $\mathrm{mt}$-lineages that we observe (especially lineages $\mathrm{S}, \mathrm{N}$ and $\mathrm{A}$ ), we propose that each lineage existed in a polymorphic state throughout its range before the appearance of the barriers to gene flow. When populations were divided, the effective population size of each subpopulation got smaller, and this resulted in genetic drift. As a result, genetic variation was lost in each area.

Although the effective barriers to gene flow explains the population genetic structure in E. peliomphala revealed in this study, we cannot tell whether this pattern was common in other sympatric species. Additional phylogeographical data on the other animals occurring around the Izu and Kanto area requires further examination.

\section{Fluctuation in population size}

This study demonstrated the lack of isolation-bydistance, i.e. a negligible correlation between genetic and geographical distances (Table 2), and the similarity between observed and expected distributions of the pairwise nucleotide differences in the Boso haplotype and in group 1 of the Kanto haplotype (Figs 5a, 5e). The results of these two analyses suggest that haplotypes $\mathrm{B}$ and $\mathrm{K}$ experienced a major recent expansion of their distributions.

From a palaeogeographical point of view, these results appear very reasonable. The Northern Boso Peninsula and the Kanto Plain became exposed as land during the Last Glacial Age (50 000-18 000 BP). After the end of the Last Glacial Age, there was a vegetational transition from coniferous forests into broad-leaved forests, accompanied by a rise in temperature at about 17 000-12 000 BP (Inada et al., 1998). Because E. peliomphala is an arboreal species that never lives in coniferous trees, the vast stretch of the newly opened area in the Kanto Plain and the Northern Boso area became suitable for colonization only after the vegetational transition. As a result, the movement of the founders northward into the new habitat should have occurred in the last $17000-12000$ years. It is noteworthy that most of the snails with B and group 1 of the $\mathrm{K}$ haplotypes are distributed in the newly opened area, which was under the sea until comparatively recently.

Tokyo Bay also rose above sea level (Fig. 9c) during the Last Glacial Maximum ( $\approx 20000 \mathrm{BP})$. Therefore, it would have been possible for the land snails to move into or out of the Southern Boso area across Tokyo Bay. However, the vegetation around the Kanto Plain and the Northern Boso Peninsula at that time was mainly coniferous forest (Inada et al., 1998), which E. peliomphala avoid. Also, with an average temperature about $7-8^{\circ} \mathrm{C}$ lower than present (Saito, 1998), it was unlikely that the arboreal land snails would have been able to travel such a long distance during the ice age. On the other hand, pollen analysis has shown that the glossyleaved forests, favoured by E. peliomphala, were present in the Southern Boso area even during the glacial age (Inada et al., 1998). It is likely that the movements of land snails in the Southern Boso area were restricted to within the glossy-leaved forests. When the temperature rose after the end of the Last Glacial Age, Tokyo Bay was re-invaded by the sea, making it impossible for land snails to move directly across it.

It is likely that when the Kanto plain became suitable for inhabitation after the end of the Last Glacial Age, E. peliomphala expanded northwards and E. brandtii southwards into new habitat. As a result, both of the species encountered each other around the Tonegawa River, the current contact zone.

\section{'Past' and 'present' hybridization between $\mathrm{E}$. peliomphala and $\mathrm{E}$. brandtii}

We detected mtDNA introgression between E. peliomphala and E. brandtii at the contact zone between the species (populations 4, 89, and also 32; Fig. 8, Table 1). Interspecific mitochondrial gene flow via hybridization has been reported in various groups of animals (Ferris et al., 1983; Spolsky \& Uzzell, 1984; Carr et al., 1986; Lamb \& Avise, 1986; Solignac \& Monnerot, 1986; Nelson et al., 1987; Lehman et al., 1991). Our studies indicate that there are also ongoing interspecific hybridization events between E. peliomphala and E. brandtii. The existence of individuals with shell morphology intermediate between those of E. peliomphala and $E$. brandtii in the same area (data not shown) also supports the idea that the species are hybridizing.

The unusual population of E. peliomphala in the Southern Boso area, which has the mtDNA haplotypes of E. brandtii (SB haplotype), should also be regarded as another example of the interspecific mtDNA introgression from E. brandtii to E. peliomphala. As this area is inhabited exclusively by E. peliomphala, recent contact between these two species in this area is impossible.

The most plausible explanation for the presence of the SB haplotypes in this population is that they are the remnants of past hybridizations. According to this hypothesis, E. brandtii may have been more widely distributed in the south during the early Pleistocene. E. brandtii would have invaded into the Southern Boso area via the landbridge and hybridization with E. peliomphala and subsequent mtDNA introgression 
taken place. After the disappearance of the landbridge, $E$. brandtii may have become extinct in the Southern Boso area but the introgressed mtDNA was maintained in the remaining E. peliomphala populations. As animal mitochondria are generally inherited maternally and clonally, evidence for such hybridizations will remain as long as maternal lineages survive. Consequently, mtDNA analysis can reveal vestiges of hybridization even after one of the two species have become extinct in a hybrid zone (Harrison, 1989).

The alternative explanation is that snails in the Southern Boso (SB) area may, in reality, be E. brandtii. E. peliomphala can be distinguished from $E$. brandtii by different shell shape, size, characteristic colour pattern, and diagnostic radial variegation. The Southern Boso population can be identified clearly as E. peliomphala based on these features. The alternative hypothesis requires convergent evolution in all of these features. Although E. brandtii shows a wide range of shell variation, a phenotype such as that found in the Southern Boso population has not been seen in the distribution range. In addition, the shell features of the Southern Boso population show the characteristic pattern of the E. peliomphala inhabiting Boso peninsula. It is thus more plausible that these snails are $E$. peliomphala but with E. brandtii -type mtDNA.

\section{Genetical interactions between E. 'p.' kunoensis and $\mathrm{E}$. peliomphala}

In the current taxonomy, E. ' $p$.' kunoensis is separated from E. peliomphala by having wider whorls (Masuda \& Habe, 1989). Although the shell whorls of $E$. ' $p$.' kunoensis inhabiting the western area, including the type locality, are distinctly wider than those of $E$. peliomphala, some intermediate forms do appear in other areas. Our finding that E. ' $p$.' kunoensis is genetically and phylogenetically divergent from E. peliomphala provides a new and objective marker for separating these taxa. As they cannot be distinguished clearly by morphology, we tentatively identified E. ' $p$.' kunoensis by the mt-genotype. It was an unexpected finding that there are several mixed populations of E. 'p.' kunoensis and E. peliomphala haplotypes at the border (populations 45 and 46) and that some snails with E. 'p.' kunoensis haplotypes occur within the range of E. peliomphala. These observations suggest hybridization between the two taxa.

Another unexpected finding was the close phylogenetic affinity of E. 'p.' kunoensis with E. brandtii rather than with $E$. peliomphala. Although the distribution ranges of E. ' $p$.' kunoensis and E. brandtii are not in contact, the mt-phylogeny (Fig. 2) indicates their evolutionary affinity. Our data suggest that E. 'p.' kunoensis is either a sister taxon of E. brandtii or a subspecies of E. peliomphala with brandti-mtDNA, due to a past introgressive hybridization. In the former case, the morphological similarity between E. 'p.' kunoensis and E. peliomphala must be a result of convergence. In order to understand the genetic interaction and the taxonomic position of $E$. ' $p$.' kunoensis in more detail, further studies should be carried out using different nuclear molecular markers.

\section{Acknowledgements}

We are grateful to Mr Y. Mitani for valuable palaeogeographical information. We also thank Mr K. Kawabe and S. Kimura for providing some samples used in this study. This work was supported by a Grant-in-Aid for Science Research for the Ministry Education, Science, Sports and Culture of Japan and Toray Science Foundation.

\section{References}

ARTER, H. E. 1990. Spatial relationship and gene flow paths between populations of the alpine snail Arianta arbustorum (Pulmonata: Helicidae). Evolution, 44, 966-980.

AVISE, J. C., ARNOLD, J., BALL, R. M. Jr, BERMINGHAM, E., LAMB, T., NEIGEL ET AL. 1987. Intra specific phylogeography: the mitochondrial DNA bridge between population genetics and systematics. Ann. Rev. Ecol. Syst., 18, 489-522.

BERMINGHAM, E. AND AVISE, J. C. 1986. Molecular zoogeography of freshwater fishes in the Southeastern United States. Genetics, 113, 939-965.

Brown, W. M., GEORGE, M. Jr AND Wilson, A. C. 1979. Rapid evolution of animal mitochondrial DNA. Proc. Natl. Acad. Sci. U.S.A., 76, 1967-1971.

CARR, S. M., BALLINGER, S. W., DERR, J. N., BLANKENSHIP, L. H. AND BICKHAM, J. w. 1986. Mitochondrial DNA analysis of hybridization between sympatric white-tailed deer and mule deer in west Texas. Proc. Natl. Acad. Sci. U.S.A., 83, 9576-9580.

CARSON, H. L., LOCKWOOD, J. P. AND CRADDOCK, E. M. 1990. Extinction and recolonization of local populations on a growing shield volcano. Proc. Natl. Acad. Sci. U.S.A., 87, 7055-7057.

CHIBA, s. 1998. Genetic variation derived from natural gene flow between sympatric species in land snails (Mandarina). Heredity, 80, 617-623.

DESAlle, R., FREEDMAN, T., PRAGER, E. M. AND WILSON, A. C. 1987. Tempo and mode of sequence evolution in mitochondrial DNA of Hawaiian Drosophila. J. Mol. Evol., 26, 157-164.

DI RIENZO, A. AND WILSON, A. C. 1991. Branching pattern in the evolutionary tree for human mitochondrial DNA. Proc. Natl. Acad. Sci. U.S.A., 88, 1597-1601.

DOURIS, V., CAMERON, R. A., RODAKIS, G. C. AND LECANIDOU, R. 1998. Mitochondrial phylogeography of the land snail 
Albinaria in Crete: long-term geological and short term vicariance effects. Evolution, 52, 116-125.

ELLSWORTH, D. L., HONEYCUTT, R. L., SILVY, N. J., BICKHAM, J. W. AND KILMSTRA, w. D. 1994. Historical biogeography and contemporary patterns of mitochondrial DNA variation in white-tailed deer from the southeastern United States. Evolution, 48, 122-136.

FELSENSTEIN, J. 1989. PHYLIP-phylogeny inference package. Vers. 3.2. Cladistics, 5, 164-166.

FERris, S. D., SAGE, R., HUANG, C. M., NEILSEN, J. T., RITTE, U. AND WILSON, A. C. 1983. Flow of mitochondrial DNA across a species boundary. Proc. Natl. Acad. Sci. U.S.A., 80, 2290-2294.

FUJITA, Y., SUZUKI, Y., TSUNODA, F. AND KIKUCHI, T. 1986. Problems in developmental history of the geological structure. In: M. Omori, Y. Hayama and M. Horiguchi (eds) Regional Geology of Japan, Part 3: KANTO, pp. 265-276. Kyoritsu shuppan, Tokyo (in Japanese).

HANFLING, B. AND BRANDL, R. 1998. Genetic differentiation of the bullhead Cottus gobio L. across watersheds in Central Europe: evidence for two taxa. Heredity, 80, 110-117.

HARRISON, R. G. 1989. Animal mitochondrial DNA as a genetic marker in population and evolutionary biology. Trends Ecol. Evol., 4, 6-11.

HUTCHINSON, C. A. III, NEWBOLD, J. E., POTTER, S. S. AND EDGELL, M. H. 1974. Maternal inheritance of mammalian mitochondrial DNA. Nature, 251, 536-538.

IMANISHI, T. 1998. DENDROMAKER for Macintosh, Version 4.1. http://www.cib.nig.ac.jp/dda/timanish/dendromaker/home. html.

INADA, A., OHAMA, K. AND SHIMAMURA, K. 1998. Vegetational history since the latter period of the Last Glacial Age around the lowland along the Shinkawa River in Yachiyo City, Chiba Prefecture, central Japan. Quat. Res. (DaiyonkiKenkyu), 37, 283-298.

JAMES, F. C. 1983. Environmental component of morphological differentiation in birds. Science, 221, 184-186.

JONES, J. S., SELANDER, R. K. AND SCHNELL, G. D. 1980. Patterns of morphological and molecular polymorphism in the land snail Cepaea nemoralis. Biol. J. Linn. Soc., 14, 359-387.

KIMURA, M. 1980. A simple method for estimating evolutionary rates of base substitutions through comparative studies of nucleotide sequences. J. Mol. Evol., 16, 111120.

KNOLL, S. AND ROWELL-RAHIER, M. 1998. Distribution of genetic variance and isolation by distance in two leaf beetle species: Oreina cacaliae and Oreina speciosissima. Heredity, 81, 412-421.

KURASAWA, H. 1972. Volcanoes and volcanic rocks in Izu Peninsula, Japan - with regard to genesis of volcanic rocks. In: M. Hoshino and H. Aoki (eds) Izu Peninsula, pp. 155184. Tokai University Press, Tokyo.

KURODA, T. AND TERAMACHI, A. 1937. Reconsideration of E. eoa - a new proposal for the phylogenetic relationships within the genus Ehuhadra. Venus, 7, 12-28 (in Japanese).

LAMB, T. AND AVISE, J. C. 1986. Directional introgression of mitochondrial DNA in a hybrid population of tree frogs: the influence of mating behavior. Proc. Natl. Acad. Sci. U.S.A., 83, 2526-2530.

LEHMAN, N., EISENHAWER, A., HANSEN, K., MECH, L. D., PETERSON, R. O., GOGAN, P. J. P. ET AL. 1991. Introgression of coyote mitochondrial DNA into sympatric North American grey wolf populations. Evolution, 45, 104-119.

LUNT, D. H., IBRAHAM, K. M. AND HEWITT, G. M. 1998. MtDNA phylogeography and postglacial patterns of subdivision in the meadow grasshopper Chorthippus paralleus. Heredity, 80, 633-641.

MASUDA, O. AND HABE, T. 1989. Land and freshwater molluscan fauna of Shizuoka Prefecture, central Japan. In: Science Reports of the Natural History Museum 3, 82 pp., 15 plates. Tokai University Press, Tokyo (in Japanese with English summary).

NELSON, K. BAKER, R. J. AND HONEYCUTT, R. L. 1987. Mitochondrial DNA and protein differentiation between hybridizing cytotypes of the white-footed mouse, Peromyscus leucopus. Evolution, 41, 864-872.

PFENNINGER, M., BAHL, A. AND STREIT, B. 1996. Isolation by distance in a population of a small land snail Trochoidea geyeri: evidence from direct and indirect methods. Proc. R. Soc. B, 263, 1211-1217.

ROGERS, A. R. 1995. Genetic evidence for a pleistocene population. Evolution, 49, 608-615.

ROGERS, A. R. AND HARPENDING, H. 1992. Population growth makes waves in the distribution of pairwise genetic differences. Mol. Biol. Evol., 9, 552-569.

ROZAS, J. AND ROZAS, R. 1999. DNASP, Version 3: an integrated program for molecular population genetics and molecular evolution analysis. Bioinformatics, 15, 174-175.

SAITO, K. 1998. Climate during the later stadial of the Last Glacial Age presumed from alluval fan distribution in Japan. J. Saitamta Univ., 47, 15-23.

SAITOU, N. AND NEI, M. 1987. The neighbor-joining method: a new method for reconstructing phylogenetic trees. Mol. Biol. Evol., 4, 406-425.

SAMBROOK, J., FRITSCH, E. F. AND MANIATIS, T. 1989. Molecular Cloning, 2nd edn. Cold Spring Harbor Laboratory Press, New York.

SANGER, F., NICKLEN, S. AND COUlSON, A. R. 1977. DNA sequencing with chain-terminating inhibitors. Proc. Natl. Acad. Sci. U.S.A., 74, 5463-5467.

SChilthuizen, M. AND LOMBAeRTS, M. 1994. Population structure and levels of gene flow in the Mediterranean land snail Albinaria corrugata. Evolution, 48, 577-586.

SLATKIN, M. AND HUDSON, R. R. 1991. Pairwise comparisons of mitochondrial DNA sequences in stable and exponentially growing populations. Genetics, 129, 555-562.

SOLIGNAC, M. AND MONNEROT, M. 1986. Race formation, speciation, and introgression within Drosophila simulans, D. mauritania, and D. sechellia inferred from mitochondrial DNA analysis. Evolution, 40, 531-539.

SPOLSKY, C. AND UZZELL, T. 1984. Natural interspecies transfer of mitochondrial DNA in amphibians. Proc. Natl. Acad. Sci. U.S.A., 81, 5802-5805. 
THOMAZ, D., GUILlER, A. AND ClARKE, B. 1996. Extreme divergence of mitochondrial DNA within species of pulmonate land snails. Proc. R. Soc. B, 263, 363-368.

THOMPSON, J. D., HIGGINS, D. G. AND GIBSON, T. J. 1994. CLUSTAL W: improving the sensitivity of progressive multiple sequence alignment through sequence writing, position specific gap penalties and weight matrix choice. Nucl. Acid Res., 22, 4637-4680.
wOODING, S. AND WARD, R. 1997. Phylogeography and Pleistocene evolution in the North American black bear. Mol. Biol. Evol., 14, 1096-1105.

WRIGHT, s. 1946. Isolation by distance under diverse systems of mating. Genetics, 31, 35-39.

ZINK, R. M. 1994. The geography of mitochondrial DNA variation, population structure, hybridization, and species limits in the fox sparrow (Passerella iliaca). Evolution, 48, 96-111. 